\title{
Low Risk
}

National Cancer Institute

\section{Source}

National Cancer Institute. Low Risk. NCI Thesaurus. Code C102403.

The potential future harm that may arise from some present action or attribute or condition is small. 